\title{
Structural Arrangement Produced by Concanavalin A Binding to Homomeric GluK2 Receptors
}

\author{
Cuauhtemoc U. Gonzalez ${ }^{1,2}{ }^{\mathbb{D}}$, Elisa Carrillo ${ }^{1}$, Vladimir Berka ${ }^{1}$ and Vasanthi Jayaraman ${ }^{1,2, *}$ \\ 1 Center for Membrane Biology, Department of Biochemistry and Molecular Biology, \\ University of Texas Health Science Center at Houston, 6431 Fannin St., Houston, TX 77030, USA; \\ Cuauhtemoc.Gonzalez@uth.tmc.edu (C.U.G.); Elisa.CarrilloFlores@uth.tmc.edu (E.C.); \\ Vladimir.Berka@uth.tmc.edu (V.B.) \\ 2 MD Anderson Cancer Center UTHealth Graduate School of Biomedical Sciences, University of Texas Health \\ Science Center at Houston, 6431 Fannin St., Houston, TX 77030, USA \\ * Correspondence: vasanthi.jayaraman@uth.tmc.edu; Tel.: +1-(713)-500-6236
}

Citation: Gonzalez, C.U.; Carrillo, E.; Berka, V.; Jayaraman, V. Structural Arrangement Produced by Concanavalin A Binding to Homomeric GluK2 Receptors. Membranes 2021, 11, 613. https:/ / doi.org/10.3390/membranes11080613

Academic Editor: Akira Naito

Received: 15 July 2021

Accepted: 9 August 2021

Published: 11 August 2021

Publisher's Note: MDPI stays neutral with regard to jurisdictional claims in published maps and institutional affiliations.

Copyright: (c) 2021 by the authors. Licensee MDPI, Basel, Switzerland. This article is an open access article distributed under the terms and conditions of the Creative Commons Attribution (CC BY) license (https:// creativecommons.org/licenses/by/ $4.0 /)$.

\begin{abstract}
Kainate receptors are members of the ionotropic glutamate receptor family. They form cation-specific transmembrane channels upon binding glutamate that desensitize in the continued presence of agonists. Concanavalin A (Con-A), a lectin, stabilizes the active open-channel state of the kainate receptor and reduces the extent of desensitization. In this study, we used singlemolecule fluorescence resonance energy transfer (smFRET) to investigate the conformational changes underlying kainate receptor modulation by Con-A. These studies showed that Con-A binding to GluK2 homomeric kainate receptors resulted in closer proximity of the subunits at the dimer-dimer interface at the amino-terminal domain as well as between the subunits at the dimer interface at the agonist-binding domain. Additionally, the modulation of receptor functions by monovalent ions, which bind to the dimer interface at the agonist-binding domain, was not observed in the presence of Con-A. Based on these results, we conclude that Con-A modulation of kainate receptor function is mediated by a shift in the conformation of the kainate receptor toward a tightly packed extracellular domain.
\end{abstract}

Keywords: kainate receptor; Concanavalin A; smFRET; electrophysiology

\section{Introduction}

Kainate receptors belong to the family of cation-permeable channels known as ionotropic glutamate receptors (iGluRs). These receptors are activated by glutamate and are important in excitatory neuronal transmission throughout the central nervous system [1-4]. Kainate receptors, like other iGluRs, are tetrameric proteins arranged as a dimer of dimers in their extracellular segments. Furthermore, each subunit of the receptor can be separated into four major domains: the two extracellular domains, which comprise the amino-terminal domain (ATD) and the agonist-binding domain (ABD); the transmembrane segments; and the cytosolic carboxy-terminal domain $[3,5,6]$. It is through induced conformational changes occurring at these domains that agonists and other small molecules regulate channel activity [7-9].

Structural and spectroscopic measurements have provided significant insight into the conformational changes underlying kainate receptor activation and desensitization [6,7,9-14]. In the resting, apo state of the kainate receptor, when there is no glutamate bound, the cleft within the bi-lobed, agonist-binding domain is open, and there are extensive interactions (coupling) between the subunits forming the dimer of the ABD. The binding of glutamate leads to closure of the ABD cleft [13,15]. In the event of coupling across the ABD dimers, the cleft closure conformational change pulls on the transmembrane segments, moving them apart, resulting in opening of the channel pore and thus, allowing the influx of cations. Decoupling of the ABD dimer interface, on the other hand, allows for the release of stress at 
the transmembrane segments. This release in stress allows for the transmembrane segments to close, preventing further influx of cations and leading to receptor desensitization $[6,7,9]$.

Exogenous jack-bean extract, Concanavalin A (Con-A), is a lectin which is known to bind to carbohydrates attached to proteins through $\mathrm{N}$-glycosylation [16-18]. Con-A has been found to modulate the function of kainate receptors by changing the extent of desensitization $[16,19]$. Using site-directed mutagenesis, it has been shown that the glycosylation sites on kainate receptors play a role in Con-A modulation $[17,18]$. These glycosylation sites are spread throughout the extracellular ATD and ABD domains, and it has not been possible to draw direct correlations between binding site, conformation, and functional modulation $[17,18,20,21]$. Functional studies have shown that Con-A binding and modulation is state-dependent. Specifically, preincubation with Con-A prior to glutamate application produces larger effects on loss of desensitization than upon co-application with glutamate simultaneously. Furthermore, the preincubation effects are less pronounced with partial agonists $[22,23]$. The differential effects due to pre-incubation provide indirect evidence for the state-dependent effect of Con-A. However, apart from these indirect measurements, the specific conformational mechanism underlying Con-A modulation is still unknown.

Here we used single-molecule fluorescence resonance energy transfer (smFRET) to study the conformational changes that underlie the reduction of desensitization in kainate receptors due to Con-A. FRET is ideally suited for such studies, as it can measure distances like a molecular ruler by detecting the extent of energy transfer between a donor and acceptor fluorophore, which are attached to specific sites on the protein of interest. Using the FRET methodology at the single-molecule level allows us to understand the conformational heterogeneity in the protein associated with each of the functional states [24-34]. We have previously used smFRET to investigate the conformations associated with the apo (unliganded), channel open/active, and desensitized states of the GluK2 homomeric kainate receptors [34]. These studies identified the ABD dimer interface as a site showing large-scale changes between active and desensitized states with no significant changes at the ATD interface across the subunits. The ABD dimer interface showed multiples states with varying degrees of decoupling, with the dimer interface being primarily tightly coupled in the resting and active states and shifting toward decoupled states upon desensitization [34]. This was consistent with the mechanism that was proposed based on cryo-EM structures of the resting and desensitized states $[6,7,9]$. Given that the subunit interfaces played a role in conformational control of function, here we studied the conformational changes underlying the reduction in desensitization of kainate receptors by Con-A by investigating the changes at the ATD and ABD subunit interfaces. Our studies show that Con-A alters the subunit interface at both the ATD and ABD favoring states that stabilize the active state of the receptor.

Prior structural and functional studies have shown that $\mathrm{Na}^{+}$ions stabilize the dimer interface at the agonist-binding domain [10,35-39]. Removal of these ions, or their replacement with $\mathrm{Cs}^{+}$, leads to an increase in population of receptor conformations that are decoupled at the dimer interface, and this, in turn, favors inactivation and stabilization of the desensitized state of the receptor [34,37]. Given that Con-A binding favors the coupled dimer interface at the agonist-binding domain, we investigated the ion modulation function of kainate receptors in the presence of Con-A to determine if the two modulators had overlapping conformational control of function.

\section{Methods}

\subsection{Generation of FRET Constructs}

GluK2 constructs containing native glutamine at site 590 from Rattus norvegicus previously used in cryo-EM and smFRET studies were used. GluK2 insertion into pcDNA3.1; replacement of cysteine to serine at sites C91, C199, and C432; and mutation of site S266 (ATD) and A479 (LBD) to cysteine has been previously described in prior studies $[6,7,33,34]$. 


\subsection{Electrophysiology}

HEK 293T cells were transfected using Lipofectamine 2000 (GluK2-wt, GluK2-ABD, and GluK2-ATD) and co-transfected with GFP at a microgram ratio of 3:1. Whole-cell patch clamp recordings were performed $24-48 \mathrm{~h}$ after transfection using fire-polished borosilicate glass (Sutter instruments, Novato, CA, USA) pipettes with 3-5 megaohms resistance that were filled with internal solution: $110 \mathrm{mM} \mathrm{CsF}, 30 \mathrm{mM} \mathrm{CsCl}, 4 \mathrm{mM} \mathrm{NaCl}, 0.5 \mathrm{mM} \mathrm{CaCl}_{2}$, $10 \mathrm{mM}$ HEPES, and $5 \mathrm{mM}$ EGTA (adjusted to $\mathrm{pH} 7.4$ with $\mathrm{CsOH}$ ). The extracellular solution consisted of $150 \mathrm{mM} \mathrm{NaCl}$ or CsCl, $2.8 \mathrm{mM} \mathrm{KCl}, 1.8 \mathrm{mM} \mathrm{CaCl}_{2}, 1.0 \mathrm{mM} \mathrm{MgCl}_{2}$, and $10 \mathrm{mM}$ HEPES and was adjusted to $\mathrm{pH} 7.4$ with $\mathrm{NaOH}$ or $\mathrm{CsOH}$. External solutions were locally applied to lifted cells using a SF-77B perfusion fast-step (Warner Instruments, Holliston, MA, USA) in the presence or absence of $1 \mathrm{mM}$ glutamate. Recordings were performed using an Axopatch 200B amplifier (Molecular Devices, San Jose, CA, USA) at $-60 \mathrm{mV}$ hold potential, acquired at $10 \mathrm{kHz}$ using pCLAMP10 software (Molecular Devices), and filtered online at $5 \mathrm{kHz}$. Single-channel recordings were performed in the outside-out patch-clamp configuration $24 \mathrm{~h}$ after transfection (GluK2-wt). Patch pipettes had a resistance of 8 to 15 megaohms when filled with an internal solution. Buffers and solution concentrations were like those used for whole cell recordings. Data were acquired at $50 \mathrm{kHz}$ and low pass filtered at $10 \mathrm{kHz}$ (Axon 200B and Digidata 1550A; Molecular Devices). The holding potential was $-100 \mathrm{mV}$. Data were further filtered at $1 \mathrm{~Hz}$. All recordings were idealized using the segmental $k$-means algorithm of QuB [40,41].

\section{3. smFRET Sample Preparation}

HEK 293T cells were transiently transfected using the JetPrime protocol at $10 \mu \mathrm{g}$ per $10-\mathrm{cm}$ plate. One day after transfection, the cells from two 10- $\mathrm{cm}$ dishes were harvested; washed with extracellular buffer (ECB) containing $135 \mathrm{mM} \mathrm{NaCl}$ or $\mathrm{CsCl}, 3 \mathrm{mM} \mathrm{KCl}$, $2 \mathrm{mM} \mathrm{CaCl}_{2}, 20 \mathrm{mM}$ glucose, and $20 \mathrm{mM}$ HEPES; and adjusted to $\mathrm{pH} 7.4$ with $\mathrm{NaOH}$ or $\mathrm{CsOH}$. Post-wash, the cells were labeled for $1 \mathrm{~h}$ at room temperature with $600 \mathrm{nM}$ of donor fluorophore Alexa 555 maleimide (ThermoFisher, Waltham, MA, USA) and $2.4 \mu \mathrm{M}$ of acceptor fluorophore Alexa 647 maleimide (ThermoFisher) in $3 \mathrm{~mL}$ of ECB. Post-labeling, the cells were washed and solubilized for $1 \mathrm{~h}$ at $4{ }^{\circ} \mathrm{C}$. Solubilization buffer contained $1 \%$ lauryl maltose neopentyl glycol (Anatrace, Maumee, OH, USA), 2 mM cholesteryl hydrogen succinate (MP Biomedicals, Irvine, CA, USA), and $\frac{1}{4}$ protease inhibitor tablet (Pierce ${ }^{\mathrm{TM}}$ ) in phosphate-buffer saline containing either $\mathrm{NaCl}$ and $\mathrm{Na}_{2} \mathrm{HPO}_{4}$ for experiments in the presence of $\mathrm{Na}^{+}$or $\mathrm{CsCl}$ and $\mathrm{K}_{2} \mathrm{HPO}_{4}$ for experiments in the absence of $\mathrm{Cs}^{+}$. Solubilized cells were filtered from unsolubilized debris by ultracentrifugation at $100,000 \times g$ for $1 \mathrm{~h}$ at $4{ }^{\circ} \mathrm{C}$ using a TLA 100.3 rotor. The supernatant was collected and kept on ice until used for smFRET samples.

\section{4. smFRET Slide Preparation}

Glass slides $(20 \times 20 \mathrm{~mm})$ were washed using bath sonication in Liquinox phosphatefree detergent (Alconox, Inc., New York, NY, USA) followed by washing with $4.3 \% \mathrm{NH}_{4} \mathrm{OH}$ and $4.3 \% \mathrm{H}_{2} \mathrm{O}_{2}$ solution. Slides were then washed with purified water and dried with nitrogen gas. Post-drying, slides were plasma cleaned using a Harrick Plasma PDC32G Plasma Cleaner followed by Vectabond (Vector Laboratories, Burlingame, CA, USA) treatment for aminosilanization. Slides were then stored under vacuum. Silicon templates (Grace Bio-Labs, Bend, OR, USA) were cleaned by sonication in methanol for $20 \mathrm{~min}$ followed by vortexing. Silicon templates were stored in clean methanol and dried with nitrogen gas when applied over Vectabond-treated slides. Slides were then treated with $50 \mu \mathrm{L}$ of PEG solution containing $0.25 \% w / w$ biotinylated PEG, $25 \% w / w$ mPEG-succinimidyl carbonate, and either $0.1 \mathrm{M} \mathrm{NaHCO}_{3}$ or $0.1 \mathrm{~m}$ Tris for $\mathrm{Na}^{+}$free conditions and stored overnight in a dark, moist environment. The following day, the slides were cleaned with purified water and dried with nitrogen gas prior to treatment with short-chain PEG solution containing $25 \mathrm{mM}$ short-chain 333 Da MS(PEG) 4 Methyl-PEG-NHS-Ester Reagent and either $0.1 \mathrm{M} \mathrm{NaHCO}_{3}$ or $0.1 \mathrm{M}$ Tris, followed by room temperature incubation for 
2-3 h. After incubation, slides were washed with purified water and dried with nitrogen gas. Silicon templates were removed, and Hybridwell chambers and press-fit tubing connectors (Grace Bio-Labs) were applied. Streptavidin solution containing $0.2 \mathrm{mg} / \mathrm{mL}$ streptavidin, $1 \mathrm{X}$ smFRET imaging buffer (1 mM DDM (n-dodecyl- $\beta$-D-maltoside), $0.2 \mathrm{mM}$ CHS (cholesteryl hydrogen succinate), and $1 \mathrm{X}$ phosphate-buffer saline containing either $\mathrm{NaCl}$ and $\mathrm{Na}_{2} \mathrm{HPO}_{4}$ or $\mathrm{CsCl}$ and $\mathrm{K}_{2} \mathrm{HPO}_{4}$ was applied inside the chamber and incubated for $10 \mathrm{~min}$, followed by washing with the appropriate $1 \mathrm{X}$ phosphate-buffer saline with or without $\mathrm{Na}^{+} .10 \mathrm{nM}$ of biotinylated Goat Anti-Mouse IgG $(\mathrm{H}+\mathrm{L})$ secondary antibody (Jackson Immunoresearch Laboratories, Inc., West Grove, PA, USA, catalog number 115-065003) was then flowed through the chamber and incubated for $20 \mathrm{~min}$, followed by washing with the appropriate $1 \mathrm{x}$ phosphate-buffer saline. Next, $10 \mathrm{nM}$ of $6 \mathrm{X}$-His Tag mouse antiTag, Clone: HIS.H8 primary antibody (Invitrogen, Waltham, MA, USA, MA1213151MG) was introduced through the chamber and incubated for $20 \mathrm{~min}$, followed by washing with the appropriate $1 x$ phosphate-buffer saline. Bovine serum albumin $(1 \mathrm{mg} / \mathrm{mL})$ was introduced into the chamber and incubated for $15 \mathrm{~min}$. Detergent-solubilized purified proteins containing $8 \mathrm{X}$-His tagged homomeric GluK2 receptors were attached to the glass slide using an in situ immuno-precipitation (SiMPull) method by applying $50 \mu \mathrm{L}$ of sample three times through the chamber and incubating for $20 \mathrm{~min} .90 \mu \mathrm{L}$ of oxygen-scavenging solution buffer system (ROXS) was applied inside the chamber containing $1 \mathrm{mM}$ methyl viologen, $1 \mathrm{mM}$ ascorbic acid, $0.01 \% w / w$ pyranose oxidase, $0.001 \% w / v$ catalase, $3.3 \% w / w$ glucose (all from Sigma-Aldrich, Inc., St. Louis, MO, USA), 1 mM DDM (Chem-Impex, Wood Dale, IL, USA), and 0.2 mM CHS (MP Biomedicals, LLC, Santa Ana, CA, USA) in phosphate-buffer saline containing either $\mathrm{NaCl}$ and $\mathrm{Na}_{2} \mathrm{HPO}_{4}$ or $\mathrm{CsCl}$ and $\mathrm{K}_{2} \mathrm{HPO}_{4}, \mathrm{pH}$ 7.4. In the glutamate-treated condition, $1 \mathrm{mM}$ glutamate, $1 \mathrm{mM}$ of $\mathrm{MnCl}_{2}$, and $1 \mathrm{mM}$ of $\mathrm{CaCl}_{2}$ were introduced into the ROXS. In the Con-A treated condition, $40 \mu \mathrm{M}$ ConA (MilliporeSigma, Burlington, MA, USA), $1 \mathrm{mM}$ of $\mathrm{MnCl}_{2}$, and $1 \mathrm{mM}$ of $\mathrm{CaCl}_{2}$ were introduced into the ROXS and incubated for $10 \mathrm{~min}$ before application of glutamatecontaining ROXS.

\section{5. smFRET Data Acquisition}

smFRET measurements were collected using a custom-built PicoQuant Microtime 200 Fluorescence Lifetime Microscope. To characterize the fluorescent behavior of both donor and acceptor fluorophores as well as the efficiency of the energy transfer between donors and acceptors, acquisition was conducted using both $532 \mathrm{~nm}$ (LDH-D-TA-530; Picoquant, Berlin, Germany) and $637 \mathrm{~nm}$ (LDH-D-C-640; Picoquant) lasers using pulsed interleaved excitation at $80 \mathrm{MHz}$. During scanning, the slide was immobilized on a scanning $x-y-z$ piezo stage (P-733.2CD; Physik Instrumente) and observed through a $100 \times$ oil-immersed lens $(100 \times 1.4$ NA; Olympus, Tokyo, Japan). Photons from samples postexcitation were then collected back through the objective and separated through a dual band dichroic beam splitter (Zt532/640rpc-UF3; AHF/Chroma, Bellows Falls, VT, USA). Prior to detection, photons were then filtered through emission filters (550 nm (FF01582/64; AHF/Semrock, Rochester, NY, USA) for the donor or $650 \mathrm{~nm}$ (2XH690/70; AHF, Tübingen-Pfrondorf, Germany) for the acceptor) and into two SPAD photodiodes (SPCM CD3516H; Excelitas Technologies, Waltham, MA, USA).

\section{6. smFRET Data Analysis}

Molecules exhibiting a donor-acceptor anticorrelation and with a single photobleaching step were used in the analysis. FRET efficiencies were calculated based on the donor and acceptor intensities. MATLAB (Mathworks, Natick, MA, USA) was used to denoise donor and acceptor traces using wavelet-based denoising [42]. Origin (OriginLab Corp, Northampton, MA, USA) was used to create smFRET histograms and traces. The total numbers of molecules used for each condition were as follows: Con- $\mathrm{A}$ treated under $\mathrm{Na}^{+}$ condition, 40 molecules for GluK2-ATD and 38 molecules for GluK2-LBD; Con-A treated under $\mathrm{Cs}^{+}$condition, 36 molecules for GluK2-LBD. 


\section{Results}

We used maleimide-thiol reaction chemistry to attach donor and acceptor fluorophores at specific sites on the GluK2 receptor via mutated cysteines. To introduce cysteines at specific sites, we used a Cys-light GluK2 receptor, where the extracellular accessible cysteines at sites C91, C199, and C432 were mutated to serines [32-34]. For investigating changes at the dimer-dimer interface at the ATD we introduced a cysteine at site 266, henceforth referred to as GluK2-ATD. To study the interface within the dimer at the ABD, we introduced a cysteine at site 479 in the Cys-light background, henceforth referred to as GluK2-ABD. These sites were optimal for the donor (Alexa 555) and acceptor (Alexa 647) fluorophore pair, as FRET was only observed for the interface of interest, and all other distances had much lower FRET efficiencies (the $R_{0}$ for Alexa 555 and Alexa 647 was $51 \AA$ ) (Figure 1). In order to attach the receptor to the imaging cover slip, we introduced an octahistidine tag on the C-terminus of the receptor, allowing us to perform in situ pulldown of solubilized receptors that were expressed in HEK-293T cells [43]. Electrophysiological measurements were performed with the smFRET constructs, GluK2-ATD and GluK2ABD, expressed in HEK-293T cells. The glutamate-mediated currents, as well as the reduction in the extent of desensitization by Con- $\mathrm{A}$ in the glutamate-mediated currents for these constructs, are shown in Figure 1 and were similar to that of the wild-type GluK2 receptor. This established that these smFRET constructs served as good models for wild-type GluK2 receptors.

To perform smFRET measurements, we transfected HEK 293T cells with GluK2ATD or GluK2-ABD and labeled them with donor and acceptor fluorophores. Detergentsolubilized membrane preparations of these cells were used for the in situ pull down of the receptor onto the coverslip. Fluorescence intensities of donor and acceptor fluorophores measured from single molecules using donor excitation (for determining FRET) were used to determine FRET efficiency between the donor and acceptor fluorophores. To ensure that only a single FRET distance was being measured, only traces exhibiting a single donor and a single acceptor photobleaching step and showing anticorrelation after the photobleaching of the acceptor were used to obtain FRET efficiencies. Representative single molecule traces and the ensemble FRET efficiency histograms from at least 30 molecules are shown in Figure 2 for GluK2-ATD and in Figures 3 and 4 for GluK2-ABD. Wavelet-based denoising was performed on the donor and acceptor traces, and these denoised traces were used to determine FRET efficiencies of the different conformational states. Histograms showing the denoised efficiencies are overlaid on the histograms from the observed traces [42].

In the presence of Con-A and glutamate, the denoised smFRET efficiency histogram for GluK2-ATD showed that the receptor exhibited a primary population that had a FRET efficiency of 0.95 , corresponding to the distance of $31 \AA$ (Figure 2), with smaller fractions at FRET efficiencies of $0.88,0.80$, and 0.72 , corresponding to distances of $37 \AA, 40 \AA$, and $44 \AA$, respectively (Figure 2). The primary FRET efficiency of 0.95 for the ATD dimer distance, at site 266, was significantly higher than the primary FRET efficiency of 0.83 that we previously observed for GluK2-ATD receptors bound to glutamate in the absence of Con-A. This shift in the FRET efficiency population histogram is shown in the overlay of the observed FRET efficiency histogram for GluK2-ATD bound to glutamate in the presence and absence of Con-A in Figure 2. Based on these data showing conformations with higher FRET efficiency corresponding to shorter distances between the dimer-dimer subunits, we could conclude that Con-A binding to GluK2 receptors led to tighter packing at the ATD. 


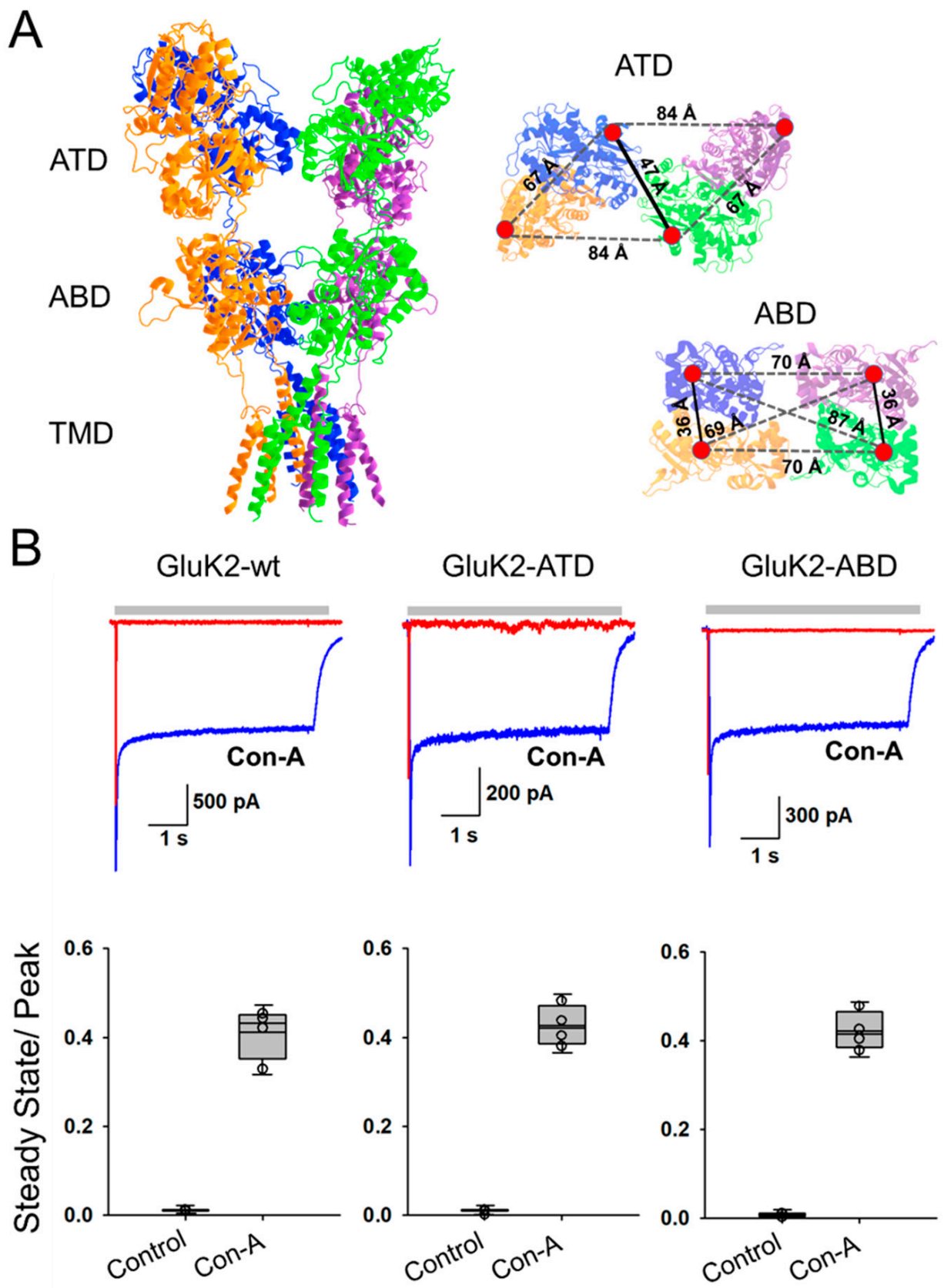

Figure 1. Depiction of the structural arrangement of homomeric GluK2 receptor and fluorophore conjugation sites. (A) Cryo-EM structure of a homomeric GluK2 receptor (PDB:5KUF) displaying the amino-terminal domain (ATD), agonist-binding domain (ABD), and transmembrane domain (TMD) and sites of fluorophore conjugation at the ATD (266) and ABD (479); top-down view shown for ATD (PDB:5KUF) and ABD (PDB:5KUH) with distances between sites 266 and 479, respectively. (B) Representative whole-cell recordings with $1 \mathrm{mM}$ of glutamate for GluK2-wt, GluK2-ATD, and GluK2-ABD in the presence (blue) or absence (red) of $40 \mu \mathrm{M}$ of Con-A (top) along with the ratio of steady-state to peak currents obtained from at least three different cells (bottom). These data show higher steady-state currents in the presence of Con-A. 
A

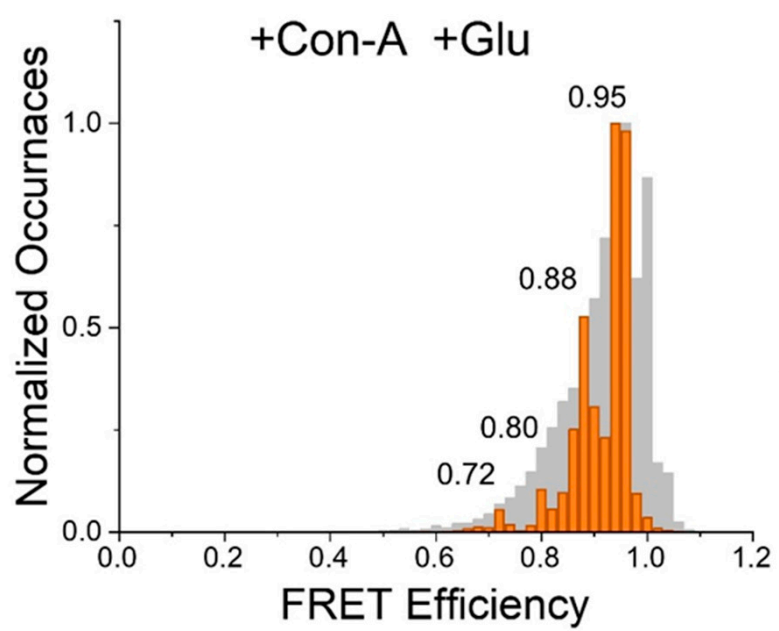

B

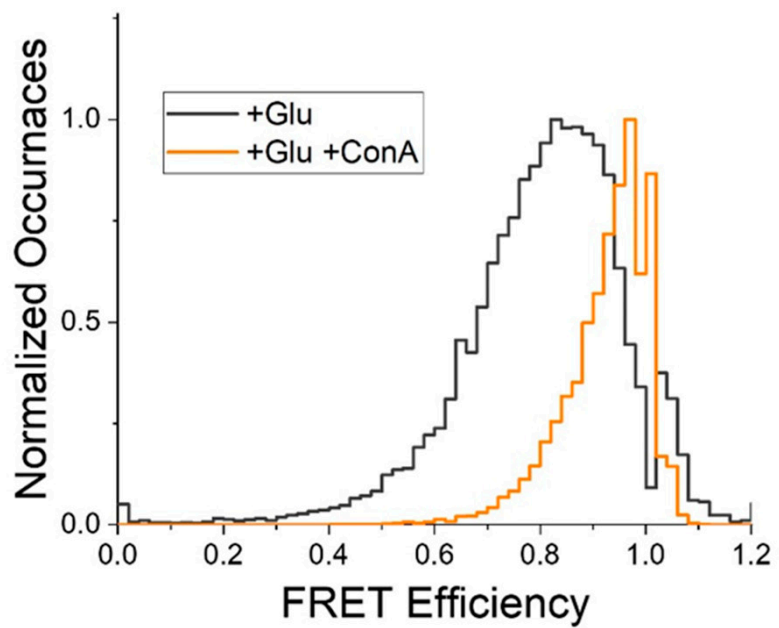

Figure 2. Conformational landscape of the distance across the dimer-dimer interface at the amino-terminal domain (ATD) of the homomeric GluK2 receptor (measured at site 266). (A) Denoised FRET efficiency histogram, in orange, overlapped onto an observed FRET efficiency histogram, in gray, depicting FRET efficiency occurrences in the presence of Con-A and glutamate. (B) Comparison between observed FRET efficiency histograms for glutamate-bound homomeric GluK2 receptors in the absence (in black) [34] and presence (in orange) of Con-A, illustrating a shift toward higher FRET efficiencies in the presence of Con-A.
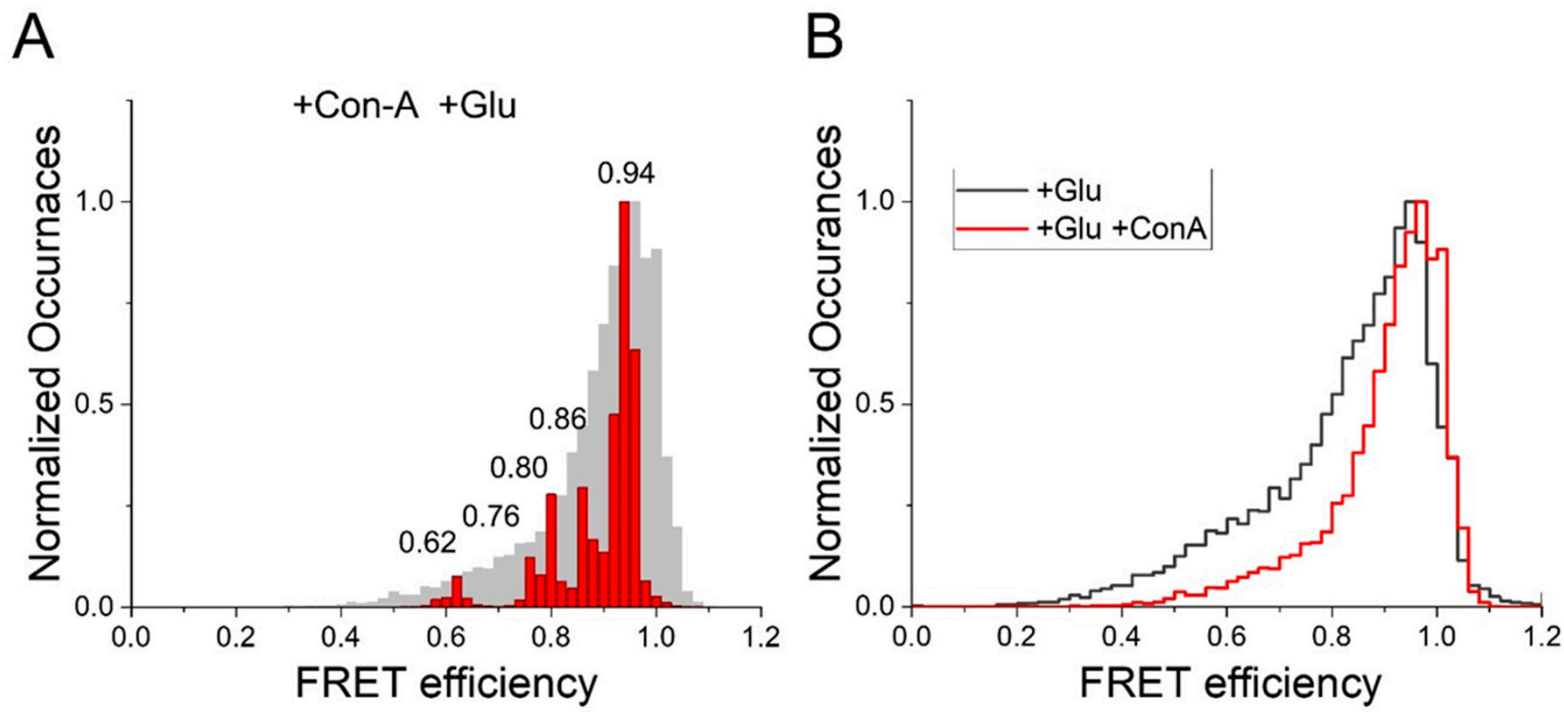

Figure 3. Conformational landscape of the distance between subunits at the dimer interface of the agonist-binding domain (ABD) of a homomeric GluK2 receptor (measured at site 479). (A) Denoised FRET efficiency histogram, in red, overlapped over observed FRET efficiency histogram, in gray, depicting FRET efficiency occurrences in the presence of Con-A and glutamate. (B) Comparison between observed FRET efficiency histograms of glutamate-bound homomeric GluK2 receptors in the absence (in black) [34] and presence (in red) of Con-A, illustrating a decrease in the low-FRET efficiency population in the presence of Con-A. 
A
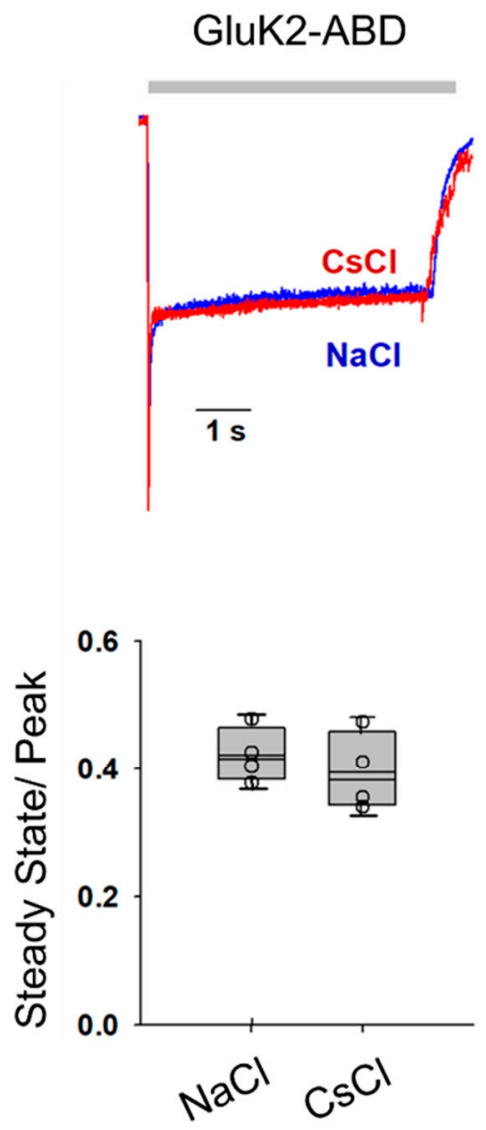

B

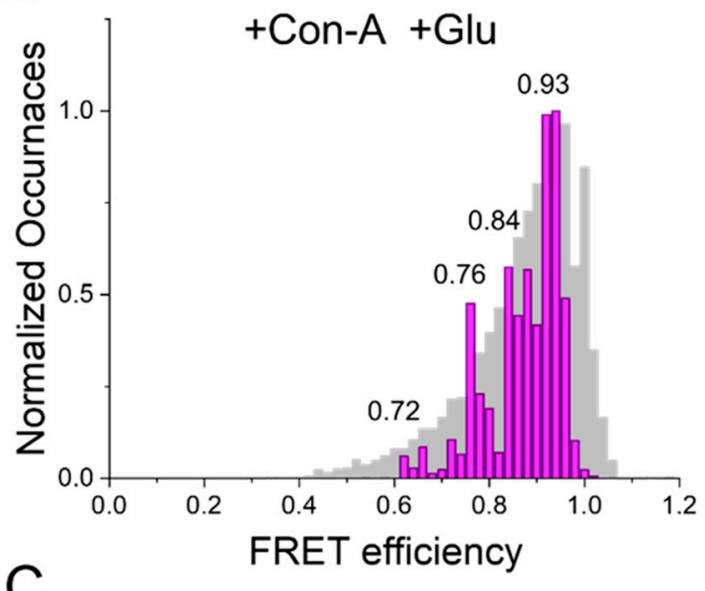

C

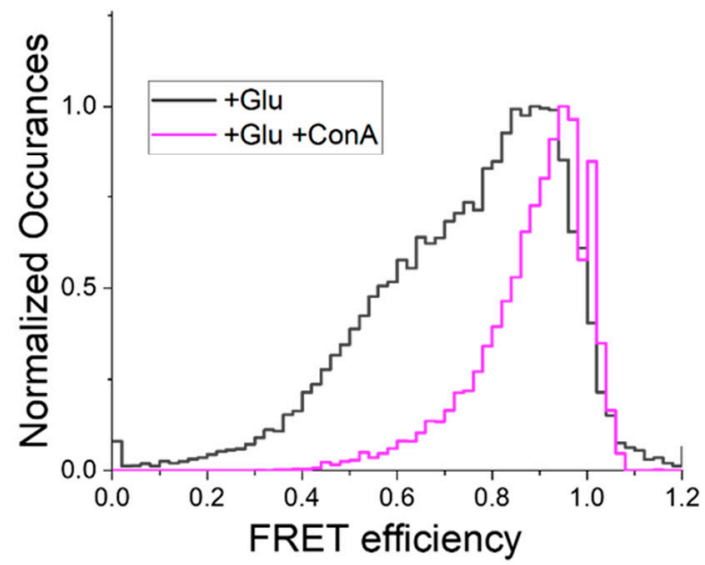

Figure 4. Effect of Con-A on ion modulation of GluK2 receptors. (A) Representative whole-cell recording with $1 \mathrm{mM}$ of glutamate and $40 \mu \mathrm{M}$ of Con-A for GluK2-ABD in the presence of either $\mathrm{CsCl}$ (red) or $\mathrm{NaCl}$ (blue) (top) along with the ratio of steady-state to peak currents obtained from at least three cells (bottom), showing no difference in steady-state response between NaCl- and CsCl-treated. (B) Denoised FRET efficiency histogram, in magenta, overlapped over the observed FRET efficiency histogram, in gray, depicting FRET efficiency occurrences in the presence of Con-A and glutamate obtained with $\mathrm{CsCl}$ replacing $\mathrm{NaCl}$. (C) Comparison between observed FRET efficiency histograms of the homomeric, glutamate-bound, GluK2 receptor obtained with $\mathrm{CsCl}$ replacing $\mathrm{NaCl}$, in the absence (in black) [34] and presence of Con-A (in magenta), illustrating a decrease in the low-FRET efficiency population in the presence of Con-A.

At the ABD dimer interface, smFRET histograms with GluK2-ABD receptors showed a major peak region at 0.94 FRET efficiency, corresponding to a distance of $32 \AA$ (Figure 3 ) in the presence of Con-A and glutamate. Additional, less populous peaks were observed at $0.86,0.80,0.76$, and 0.62 , corresponding to $38 \AA, 40 \AA, 42 \AA$, and $47 \AA$, respectively (Figure 3 ). While conformations with similar FRET efficiencies were observed previously for the GluK2 receptors bound to glutamate in the absence of Con- $\mathrm{A}$, the fraction of receptors in the high FRET states was significantly lower than that observed in the presence of Con-A. This shift in population to higher FRET efficiency states in the presence of Con-A can be seen in the overlay of the FRET efficiency histogram of GluK2-ABD bound to glutamate in the presence and absence of Con-A (Figure 3B). Prior structural and spectroscopic investigations of the $\alpha$-amino-3-hydroxy-5-methyl-4-isoxazolepropionic acid receptor (AMPAR) and kainate receptors have shown that decoupling of the agonist-binding dimer drives desensitization in these receptors $[6,9,44]$. Thus, our data, which show a shift toward a more coupled dimer interface at the agonist-binding domain in the presence of Con-A, suggest that Con-A favors activation and reduces desensitization by allosterically stabilizing the dimer interface at the agonist-binding domain. 
To further investigate the changes at the dimer interface of the ABD caused by Con-A binding, we studied the effect of Con-A on the $\mathrm{Na}^{+}$modulation of kainate receptor function. For investigating $\mathrm{Na}^{+}$ion modulation, we compared the whole-cell currents from GluK2ABD homomeric receptors mediated by $10 \mathrm{mM}$ glutamate in the presence of Con-A with $\mathrm{Na}^{+}$ions in the extracellular buffer to those measured in the extracellular buffer when $\mathrm{Na}^{+}$ was replaced with $\mathrm{Cs}^{+}$(Figure $4 \mathrm{~A}$ ). No significant differences were observed in the currents when $\mathrm{Na}^{+}$was replaced with $\mathrm{Cs}^{+}$in the presence of Con-A. These results in the presence of Con-A are in contrast with prior investigations showing a large decrease in currents when $\mathrm{Na}^{+}$was replaced with $\mathrm{Cs}^{+}$in the absence of Con-A [37]. Additionally, the extent of the residual current (non-desensitizing) due to stabilization with Con-A was similar in $\mathrm{Cs}^{+}$(Figure 4A) and in $\mathrm{Na}^{+}$(Figure 1). These investigations showed that in the presence of Con-A, the $\mathrm{Na}^{+}$ion modulation of GluK2 receptor function was not observed and was consistent with the smFRET observations that showed that Con-A stabilized the ABD dimer interface and thus, removed the need for stabilization by $\mathrm{Na}^{+}$ions. To further confirm that the stabilization of the dimer interface in the presence of Con-A was maintained in the presence of $\mathrm{Cs}^{+}$ions, we investigated the distances at the dimer interface using smFRET. The smFRET histogram obtained with GluK2-ABD receptors when $\mathrm{Na}^{+}$ions were replaced with $\mathrm{Cs}^{+}$ions (Figure $4 \mathrm{~B}$ ) was similar to that obtained with $\mathrm{Na}^{+}$ions (Figure 3). The shift to higher efficiency FRET conformations in the presence of Con-A relative to those previously reported in its absence in measurements performed when $\mathrm{Na}^{+}$ions were replaced with $\mathrm{Cs}^{+}$ions is shown by overlapping the FRET efficiency histograms (Figure 4C). Overall, the smFRET data show that Con-A favors a more coupled dimer interface even when $\mathrm{Na}^{+}$ ions are replaced with $\mathrm{Cs}^{+}$ions, and this, in turn, can be related to the similar whole cell currents observed in both $\mathrm{Na}^{+}$ions and $\mathrm{Cs}^{+}$ions.

\section{Discussion}

Lectins such as Con-A are proteins that bind specifically to carbohydrates, glycoproteins, and glycolipids. The pharmacological effects of Con-A on kainate receptors have been studied extensively in both native and heterologous expression systems [16-19,36,45,46]. These studies have shown that Con-A increases the steady-state response of kainate receptors while not altering the kinetics for desensitization. To account for these electrophysiological observations, a kinetic mechanism involving multiple open states has been proposed, with Con-A shifting the population between these states. Additionally, mutational studies have shown that Con-A binds irreversibly to nine $N$-glycosylated amino acid residues located near the agonist-binding domain [18]. Given the multiple Con-A binding sites and the fact that tetrameric Con-A is more effective than the dimeric succinyl Con-A [38], it has been proposed that Con-A may act by restricting protein movements in the ABD. Consistent with the hypothesis that Con-A alters the agonist-binding domain, Con-A has been shown to have differential effects on currents mediated by agonists of differing efficacy [23]. These biochemical and functional studies provide indirect evidence of a shift in the conformational landscape of the agonist-binding domain as the mechanism underlying Con-A modulation of kainate receptors, and our smFRET investigations presented here provide insight into the specific conformations and shifts induced by Con-A binding.

Previous smFRET investigations allowed us to characterize the conformational landscape of the extracellular domain of GluK2 receptors in the apo (unliganded), glutamatebound form (where the receptor was primarily desensitized) as well as the glutamate-bound D776K mutant receptor (where the receptor was primarily in the open active state) [34]. These studies showed that the dimer interface at the agonist-binding domain exhibits varying degrees of decoupling when the GluK2 receptor is bound to glutamate, while in the glutamate-bound form of the D776K mutant, the dimer interface of the agonist-binding domain exists primarily in a tightly coupled conformation. These studies suggested that the lower FRET (longer distance) decoupled states at the dimer interface of the ABD correlated to the desensitized state conformations, while the high FRET (shorter distance) coupled state at the dimer interface of the ABD represented the active, open-channel state 
of the receptor. The smFRET histograms for GluK2 receptors with Con-A at the dimer interface of the agonist-binding domain studied here showed a shift toward a higher FRET population, and the shift was consistent with the higher residual currents observed in the whole-cell recordings. These results suggest that modulation via Con-A is through a conformational selection process wherein conformation with the coupled dimer interface of the agonist-binding domain is favored.

This mechanism of Con-A modulation is further confirmed by the loss in $\mathrm{Na}^{+}$ion modulation in the presence of Con-A. $\mathrm{Na}^{+}$ions bind to the agonist-binding domain dimer interface and stabilize the interface. Replacing $\mathrm{Na}^{+}$with $\mathrm{Cs}^{+}$ions, which bind with a significantly lower affinity at the dimer interface, leads to lower currents and decreased stability of desensitized states in GluK2 receptors. This functional change is reflected in the higher population of lower FRET states in the presence of $\mathrm{Cs}^{+}$, further supporting the correlation between the decoupling at the dimer interface and the desensitization of the receptor. In this study, we showed that in the presence of Con-A, both function and conformational spread was unaltered when $\mathrm{Na}^{+}$was replaced with $\mathrm{Cs}^{+}$ions, as $\mathrm{Na}^{+}$was no longer required for stabilization of the agonist-binding domain interface. Overall, our smFRET data showed a tighter packing at both the ATD and ABD subunit interfaces in the GluK2 receptor in the presence of Con-A that underlay the observed functional changes.

All ionotropic glutamate receptors are N-glycosylated, and deficiencies associated with glycosylation have been implicated in a number of diseases [47]. Interestingly, it has been shown that receptors without glycosylation still maintain their primary glutamategated ion channel function [17]. However, these studies were done using isolated receptors. The present study, along with prior functional studies, shows that lectins such as Con-A can modulate function by stabilizing extracellular domains upon binding to glycosylation sites. This raises the question as to whether endogenous proteins present in synapses can modulate ionotropic glutamate receptors by binding to glycosylation sites in a manner similar to what is seen for Con-A. This would imply that deficiencies in glycosylation might not affect isolated receptor function, but they would alter the modulatory effect of these proteins on receptor function in the context of the interacting proteins and thus, alter excitatory transmission. Recent studies have shown that several endogenous proteins, such as those that belong to the C1q/TNF superfamily, have a similar beta sheet fold as Con-A [48], and these have been shown to bind to ionotropic glutamate receptors. Among the most studied and better understood is cerebellin, an endogenous soluble protein, which forms a tripartite complex with ionotropic glutamate delta receptors and the presynaptic transmembrane protein, neurexin $1 \beta[49,50]$. The modulatory mechanism through which these proteins work is still largely unknown. Future studies on the modulatory mechanism mediated by such C1q/TNF superfamily proteins, on the ionotropic glutamate receptors, and on the possible role of glycosylation on such modulation will shed light on whether these share common pathways to those observed here for Con-A binding to kainate receptors.

Author Contributions: V.J. and C.U.G. contributed toward the conceptualization; E.C. acquired the electrophysiology data; C.U.G. and V.B. acquired and analyzed smFRET data; V.J., C.U.G., E.C. and V.B. wrote and edited the manuscript. All authors have read and agreed to the published version of the manuscript.

Funding: This work was funded by Training Interdisciplinary Pharmacology Scientists (TIPS) Program Grant Fellowship T32 GM120011 to C.U.G., National Institutes of Health Grant R35 GM122528 to V.J., and American Heart Association Fellowship 18POST34030189 to E.C.

Institutional Review Board Statement: No humans or animals were used.

Informed Consent Statement: Not applicable.

Data Availability Statement: The data generated, analyzed, and presented in this study are available from the corresponding author on reasonable request.

Acknowledgments: We would like to thank Drew Dolino and Ryan Durham for providing comments and editing the manuscript. 
Conflicts of Interest: Authors declare that they have no conflict of interest.

\section{References}

1. Dingledine, R.; Borges, K.; Bowie, D.; Traynelis, S.F. The Glutamate Receptor Ion Channels. Pharmacol. Rev. 1999, 51, 7-61.

2. Traynelis, S.F.; Wollmuth, L.P.; Mcbain, C.J.; Menniti, F.S.; Vance, K.M.; Ogden, K.K.; Hansen, K.B.; Yuan, H.; Myers, S.J.; Dingledine, R. Glutamate Receptor Ion Channels: Structure, Regulation, and Function. Pharmacol. Rev. 2010, 62, 405-496. [CrossRef]

3. Contractor, A.; Mulle, C.; Swanson, G.T. Kainate Receptors Coming of Age: Milestones of Two Decades of Research. Trends Neurosci. 2011, 34, 154-163. [CrossRef]

4. $\quad$ Popescu, G.K. Modes of Glutamate Receptor Gating. J. Physiol. 2012, 590, 73-91. [CrossRef]

5. Hollmann, M.; Maron, C.; Heinemann, S. N-Glycosylation Site Tagging Suggests a Three Transmembrane Domain Topology for the Glutamate Receptor GluR1. Neuron 1994, 13, 1331-1343. [CrossRef]

6. Meyerson, J.; Chittori, S.; Merk, A.; Rao, P.; Hee Han, T.; Serpe, M.; Mayer, M.L.; Subramaniam, S. Structural Basis of Kainate Subtype Glutamate Receptor Desensitization. Nature 2016, 537, 567-571. [CrossRef]

7. Meyerson, J.R.; Kumar, J.; Chittori, S.; Rao, P.; Pierson, J.; Bartesaghi, A.; Mayer, M.L.; Subramaniam, S. Structural Mechanism of Glutamate Receptor Activation and Desensitization. Nature 2014, 514, 328-334. [CrossRef] [PubMed]

8. Nayeem, N.; Mayans, O.; Green, T. Conformational Flexibility of the Ligand-Binding Domain Dimer in Kainate Receptor Gating and Desensitization. J. Neurosci. 2011, 31, 2916-2964. [CrossRef] [PubMed]

9. Schauder, D.M.; Kuybeda, O.; Zhang, J.; Klymko, K.; Bartesaghi, A.; Borgnia, M.J.; Mayer, M.L.; Subramaniam, S. Glutamate Receptor Desensitization Is Mediated by Changes in Quaternary Structure of the Ligand Binding Domain. Proc. Natl. Acad. Sci. USA 2013, 110, 5921-5926. [CrossRef] [PubMed]

10. Dawe, G.B.; Musgaard, M.; Andrews, E.D.; Daniels, B.A.; Aurousseau, M.R.P.; Biggin, P.C.; Bowie, D. Defining the Structural Relationship between Kainate-Receptor Deactivation and Desensitization. Nat. Struct. Mol. Biol. 2013, 20, 1054-1061. [CrossRef]

11. Twomey, E.C.; Yelshanskaya, M.V.; Grassucci, R.A.; Frank, J.; Sobolevsky, A.I. Structural Bases of Desensitization in AMPA Receptor-Auxiliary Subunit Complexes. Neuron 2017, 94, 569-580. [CrossRef]

12. Twomey, E.C.; Yelshanskaya, M.V.; Grassucci, R.A.; Frank, J.; Sobolevsky, A.I. Channel Opening and Gating Mechanism in AMPA-Subtype Glutamate Receptors. Nature 2017, 549, 60-65. [CrossRef]

13. Naur, P.; Vestergaard, B.; Skov, L.K.; Egebjerg, J.; Gajhede, M.; Kastrup, J.S. Crystal structure of the kainate receptor GluR5 ligand-binding core in complex with (S)-glutamate. FEBS Lett. 2005, 579, 1154-1160. [CrossRef] [PubMed]

14. Yelshanskaya, M.V.; Li, M.; Sobolevsky, A.I. Structure of an Agonist-Bound Ionotropic Glutamate Receptor. Science 2014, 345, 1070-1074. [CrossRef] [PubMed]

15. Mayer, M.L. Crystal Structures of the GluR5 and GluR6 Ligand Binding Cores: Molecular Mechanisms Underlying Kainate Receptor Selectivity. Neuron 2005, 45, 539-552. [CrossRef] [PubMed]

16. Yue, K.-T.; Macdonald, J.F.; Pekhletski, R.; Hampson, D.R. Differential Effects of Lectins on Recombinant Glutamate Receptors. Eur. J. Pharmacol. Mol. Pharmacol. 1995, 291, 229-235. [CrossRef]

17. Everts, I.; Villmann, C.; Hollmann, M. N-Glycosylation Is Not a Prerequisite for Glutamate Receptor Function but Is Essential for Lectin Modulation. Mol. Pharmacol. 1997, 52, 861-873. [CrossRef]

18. Everts, I.; Petroski, R.; Kizelsztein, P.; Teichberg, V.I.; Heinemann, S.F.; Hollmann, M. Lectin-Induced Inhibition of Desensitization of the Kainate Receptor GluR6 Depends on the Activation State and Can Be Mediated by a Single Native or Ectopic N-Linked Carbohydrate Side Chain. J. Neurosci. 1999, 19, 916-927. [CrossRef] [PubMed]

19. Mayer, M.L.; Vyklicky, L. Concanavalin A Selectively Reduces Desensitization of Mammalian Neuronal Quisqualate Receptors. Proc. Natl. Acad. Sci. USA 1989, 86, 1411-1415. [CrossRef]

20. Galen Wo, Z.; Oswald, R.E. A Topological Analysis of Goldfish Kainate Receptors Predicts Three Transmembrane Segments. J. Biol. Chem. 2000, 270, 2000-2009. [CrossRef]

21. Taverna, F.A.; Wang, L.Y.; MacDonald, J.F.; Hampson, D.R. A Transmembrane Model for an Ionotropic Glutamate Receptor Predicted on the Basis of the Location of Asparagine-Linked Oligosaccharides. J. Biol. Chem. 1994, 269, 14159-14164. [CrossRef]

22. Sahara, Y.; Noro, N.; Iida, Y.; Soma, K.; Nakamura, Y. Glutamate Receptor Subunits GluR5 and KA-2 Are Coexpressed in Rat Trigeminal Ganglion Neurons. J. Neurosci. 1997, 17, 6611-6620. [CrossRef]

23. Fay, A.-M.L.; Bowie, D. Concanavalin-A Reports Agonist-Induced Conformational Changes in the Intact GluR6 Kainate Receptor. J. Physiol. 2006, 572, 201-213. [CrossRef]

24. Landes, C.F.; Rambbhadran, A.; Taylor, J.N.; Salatan, F.; Jayaraman, V. Structural Landscape of Isolated Agonist-Binding Domains from Single AMPA Receptors. Nat. Chem. Biol. 2011, 7, 168-173. [CrossRef]

25. Ramaswamy, S.; Cooper, D.; Poddar, N.; MacLean, D.M.; Rambhadran, A.; Taylor, J.N.; Uhm, H.; Landes, C.F.; Jayaraman, V. Role of Conformational Dynamics in $\alpha$-Amino-3-Hydroxy-5-Methylisoxazole-4-Propionic Acid (AMPA) Receptor Partial Agonism. J. Biol. Chem. 2012, 287, 43557-43564. [CrossRef] [PubMed]

26. MacLean, D.M.; Ramaswamy, S.S.; Du, M.; Howe, J.R.; Jayaraman, V. Stargazin Promotes Closure of the AMPA Receptor Ligand-Binding Domain. J. Gen. Physiol. 2014, 144, 503-512. [CrossRef]

27. Dolino, D.M.; Cooper, D.; Ramaswamy, S.; Jaurich, H.; Landes, C.F.; Jayaraman, V. Structural Dynamics of the Glycine-Binding Domain of the N-Methyl-D-Aspartate Receptor. J. Biol. Chem. 2014, 290, 797-804. [CrossRef] [PubMed] 
28. Sirrieh, R.E.; MacLean, D.M.; Jayaraman, V. A Conserved Structural Mechanism of NMDA Receptor Inhibition: A Comparison of Ifenprodil and Zinc. J. Gen. Physiol. 2015, 146, 173-181. [CrossRef]

29. Dolino, D.M.; Adariani, S.R.; Shaikh, S.A.; Jayaraman, V.; Sanabria, H. Conformational Selection and Submillisecond Dynamics of the Ligand-Binding Domain of the N-Methyl-d-Aspartate Receptor. J. Biol. Chem. 2016, 291, 16175-16185. [CrossRef]

30. Shaikh, S.A.; Dolino, D.M.; Lee, G.; Chatterjee, S.; MacLean, D.M.; Flatebo, C.; Landes, C.F.; Jayaraman, V. Stargazin Modulation of AMPA Receptors. Cell Rep. 2016, 17, 328-335. [CrossRef] [PubMed]

31. Dolino, D.M.; Chatterjee, S.; MacLean, D.M.; Flatebo, C.; Bishop, L.D.C.; Shaikh, S.A.; Landes, C.F.; Jayaraman, V. The StructureEnergy Landscape of NMDA Receptor Gating. Nat. Chem. Biol. 2017, 13, 1232-1238. [CrossRef]

32. Litwin, D.B.; Durham, R.J.; Jayaraman, V. Single-molecule FRET methods to study glutamate receptors. In Methods in Molecular Biology; Humana Press Inc.: Totowa, NJ, USA, 2019; Volume 1941, pp. 3-16.

33. Litwin, D.B.; Paudyal, N.; Carrillo, E.; Berka, V.; Jayaraman, V. The Structural Arrangement and Dynamics of the Heteromeric GluK2/GluK5 Kainate Receptor as Determined by SmFRET. Biomembranes 2020, 1862, 183001. [CrossRef] [PubMed]

34. Litwin, D.B.; Carrillo, E.; Shaikh, S.A.; Berka, V.; Jayaraman, V. The Structural Arrangement at Intersubunit Interfaces in Homomeric Kainate Receptors. Sci. Rep. 2019, 9, 6969. [CrossRef]

35. Bowie, D. External Anions and Cations Distinguish between AMPA and Kainate Receptor Gating Mechanisms. J. Physiol. 2002, 539, 725-733. [CrossRef] [PubMed]

36. Wong, A.Y.C.; Fay, A.-M.L.; Bowie, D. External Ions Are Coactivators of Kainate Receptors. J. Neurosci. 2006, $26,5750-5755$. [CrossRef] [PubMed]

37. Plested, A.J.R.; Vijayan, R.; Biggin, P.C.; Mayer, M.L. Molecular Basis of Kainate Receptor Modulation by Sodium. Neuron 2008, 58, 720-735. [CrossRef] [PubMed]

38. Bowie, D.; Garcia, E.P.; Marshall, J.; Traynelis, S.F.; Lange, D.G. Allosteric Regulation and Spatial Distribution of Kainate Receptors Bound to Ancillary Proteins. J. Physiol. 2003, 547, 373-385. [CrossRef]

39. Paramo, T.; Brown, P.M.G.E.; Musgaard, M.; Bowie, D.; Biggin, P.C. Functional Validation of Heteromeric Kainate Receptor Models. Biophys. J. 2017, 113, 2173-2177. [CrossRef] [PubMed]

40. Qin, F. Restoration of Single-Channel Currents Using the Segmental k-Means Method Based on Hidden Markov Modeling. Biophys. J. 2004, 86, 1488-1501. [CrossRef]

41. Nicolai, C.; Sachs, F. Solving Ion Channel Kinetics with the QuB Software. Biophys. Rev. Lett. 2014, 8, 191-211. [CrossRef]

42. Shuang, B.; Cooper, D.; Taylor, J.N.; Kisley, L.; Chen, J.; Wang, W.; Li, C.B.; Komatsuzaki, T.; Landes, C.F. Fast StepTransition and State Identification (STaSI) for Discrete Single-Molecule Data Analysis. J. Phys. Chem. Lett. 2014, 5, 3157-3161. [CrossRef] [PubMed]

43. Jain, A.; Liu, R.; Ramani, B.; Arauz, E.; Ishitsuka, Y.; Ragunathan, K.; Park, J.; Chen, J.; Xiang, Y.K.; Ha, T. Probing Cellular Protein Complexes Using Single-Molecule Pull-Down. Nature 2011, 473, 484-488. [CrossRef] [PubMed]

44. Dürr, K.L.; Chen, L.; Stein, R.A.; de Zorzi, R.; Folea, I.M.; Walz, T.; McHaourab, H.S.; Gouaux, E. Structure and Dynamics of AMPA Receptor GluA2 in Resting, Pre-Open, and Desensitized States. Cell 2014, 158, 778-792. [CrossRef]

45. Huettner, J.E. Glutamate Receptor Channels in Rat DRG Neurons: Activation by Kainate and Quisqualate and Blockade of Desensitization by Con A. Neuron 1990, 5, 255-266. [CrossRef]

46. Paternain, A.V.; Rodríguez-Moreno, A.; Villarroel, A.; Lerma, J. Activation and Desensitization Properties of Native and Recombinant Kainate Receptors. Neuropharmacoloy 1998, 37, 1249-1259. [CrossRef]

47. Hennet, T.; Cabalzar, J. Congenital disorders of glycosylation: A concise chart of glycocalyx dysfunction. Trends Biochem Sci. 2015, 40, 377-384. [CrossRef]

48. Ressl, S.; Vu, B.K.; Vivona, S.; Martinelli, D.C.; Südhof, T.C.; Brunger, A.T. Structures of C1q-like proteins reveal unique features among the C1q/TNF superfamily. Structure 2015, 23, 688-699. [CrossRef]

49. Matsuda, K.; Yuzaki, M. Cbln1 and the $\delta 2$ glutamate receptor-an orphan ligand and an orphan receptor find their partners. Cerebellum 2012, 11, 78-84. [CrossRef]

50. Matsuda, K. Synapse organization and modulation via C1q family proteins and their receptors in the central nervous system. Neurosci. Res. 2017, 116, 46-53. [CrossRef] 